\title{
Sigurnost posjetitelja i upravljanje rizicima u šumskim predjelima zaštićenih područja prirode
}

\author{
Matija Landekić, Ivan Martinić, Matija Bakarić, Mario Šporčić
}

\begin{abstract}
Nacrtak - Abstract
Posljednja dva desetljeća obilježena su, osobito u razvijenim zemljama zapadne Europe $i$ svijeta, značajnim promjenama u upravljanju zdravljem $i$ sigurnošću posjetitelja u šumskim ekosustavima zaštićenih područja prirode. Uprave zaštićenih područja sve više razvijaju različite modele i provode mnoge elemente sustava upravljanja rizicima pri posjećivanju. Takvi sustavi razumijevaju koncepte kojima se usmjeravaju akcije za upravljanje rizicima radi povećanja sigurnosti posjetitelja, osobito kod oblika koji zahtijevaju njihovo naglašeno fizičko angažiranje. U uvodnom dijelu rada prikazuje se uloga, svrha i cilj sustava upravljanja rizicima pri posjećivanju zaštićenih područja. U središnjem dijelu rada iznose se, na primjeru pješačke infrastrukture u zaštićenom području, negativni aspekti postojećega stanja, posljedice neadekvatne kontrole rizika te kategorizacija mogućih opasnosti. U rezultatima rada, na konkretnim primjerima, pojašnjavaju se tri ključna segmenta sustava upravljanja rizicima: (a) protokol inspekcije rizika; (b) shema programiranoga odmaranja i (c) uloga interaktionih mrežnih alata. U završnom dijelu rada prikazuje se operacionalizacija i provedba sustava upravljanja rizicima pri posjećivanju zaštićenoga područja na primjeru »pješačke« parkovne infrastrukture.
\end{abstract}

Ključne riječi: šumarstvo, zaštićena područja, sigurnost posjetitelja, upravljanje rizicima

\section{Uvod - Introduction}

Suvremeni turistički trendovi danas razumijevaju sve veću osviještenost potrošača te zagovaraju koncepte "povratka čovjeka prirodi« i proaktivno konzumiranje »zelenoga turizma" (Landekić i dr. 2018). Iz godine u godinu broj posjetitelja u zaštićenim područjima prirode širom svijeta stalno raste, što za sobom povlači i povećani rizik od mogućih nezgoda s različitim posljedicama. Problematikom mogućih opasnosti i ugroze za posjetitelje te sigurnost pri posjećivanju zaštićenih područja proučavali su brojni autori (Stephens i dr. 2005, Newman 2007, Forrester i Holstege 2009, Stock i dr. 2012). Posljednjih nekoliko godina dogodile su se značajne promjene, osobito $u$ razvijenim zemljama zapadne Europe i svijeta, s obzirom na uvjete i modele upravljanja zdravljem i sigurnošću posjetitelja s jedne strane, te na zaštitu prirode $s$ druge strane. $U$ državama razvijenih parkovnih sustava (Australija, SAD,
Velika Britanija i sl.) određeno je da institucije koje upravljaju zaštićenim područjem i one koje se bave turističkom djelatnošću pružanja usluge posjećivanja, moraju razviti model za upravljanje rizicima pri posjećivanju i rekreacijskim aktivnostima (engl. Visitor Risk Management). Takav model definira se kao "sustavna identifikacija, analiza i kontrola širokoga spektra rizika pri posjećivanju i rekreacijskim aktivnostima posjetitelja, koje prijete parkovnoj upravi ili njihovoj sposobnosti da ostvare svoje ciljeve« (WACALM 1997a).

Razvojem rekreacijskih aktivnosti u zaštićenim područjima Republike Hrvatske, koje su obilježene povećanjem i sadržaja odnosno oblika i intenziteta, posljednjih se godina sve više susrećemo s većim brojem slučajeva ozljeđivanja i smrtnoga stradanja (Martinić i dr. 2015, Popović 2019). To je posljedica povećanja broja posjetitelja, njihove sve veće mobilnosti i interesa za »intenziviranjem « boravka, ali i veće ponude rekreacijskih aktivnosti s uključenim 
izraženijim rizikom, kao što su slobodno penjanje, brdski biciklizam, paragliding, adrenalinski parkovi i dr. Gotovo svi oblici rekreacije sa sobom nose i pripadajući rizik, pri čemu upravo takav rizik privlači mnoge ljude, posebno u adrenalinskim sportovima. Kako bi se zaštićena područja brinula o svojim posjetiteljima i zadržala dobar ugled, jedan od zadataka uprave zaštićenih područja jest taj rizik svesti na najmanju moguću mjeru. U tom smislu možemo govoriti o novom aspektu zadaće parkovnih uprava u kojem su one usmjerene na smanjivanje mogućih šteta u slučaju ozljeđivanja i/ili stradanja posjetitelja. Pri tom važan element upravljanja zaštićenim područjima postaje planiranje i upravljanje rizicima vezanima uz rekreacijske aktivnosti posjetitelja (Martinić 2010).

Premda je općenito prihvaćeno da su posjetitelji zaštićenih područja odgovorni za osobnu sigurnost kad se odluče za rekreacijske aktivnosti, u praksi se značajne teškoće javljaju oko razgraničenja što je osobna, a što parkovna odgovornost u slučaju nesreće (Martinić 2010). Zbog otežanoga razgraničavanja odgovornosti u slučajevima ozljeđivanja posjetitelja sustav upravljanja rizicima u zaštićenim područjima prirode važan je alat za uspostavu djelotvornoga i sigurnoga okruženja za posjetitelje. On je okvir za procese i postupke koji se koriste kako bi se osiguralo da institucija koja upravlja zaštićenim područjem može ispuniti sve zahtjeve potrebne za postizanje svojih poslovnih ciljeva i standarda sigurnosti.

\section{Opasnosti i posljedice neprovođenja sustavnoga upravljanja rizicima pri posjećivanju zaštićenih područja Dangers and consequences of non- implementation of systematic risk management in visiting protected areas}

Svaka uprava zaštićenoga područja ima dužnost osigurati, koliko je to izvedivo, da posjetitelji u što manjoj mjeri budu izloženi nepotrebnim rizicima. Neosporiva odgovornost uprave zaštićenoga područja osiguranje je adekvatne i sigurne parkovne infrastrukture. Na lokalitetima gdje rizik postoji zbog prirodnih obilježja, npr. litice, rijeke, potoci, jezera, padajuće grane s drveća ili padajuće stijene, ne sugerira se ograničiti pristup ili poduzeti druge restriktivne mjere koje umanjuju ugodnost boravka posjetitelja samo iz straha da bi nesreća mogla rezultirati procesuiranjem i odštetnim zahtjevom (slika 1). Bit razumnoga upravljanja rizikom jest usredo- točiti resurse na smanjenje najozbiljnijih rizika. Prioritetne rizike čine oni koji se najčešće javljaju i oni koji imaju mogućnost za najveću štetnu posljedicu (VSCG 2015, Landekić 2020).

Opasnosti koje se pojavljuju pri posjećivanju u prirodi mogu se podijeliti na objektivne i subjektivne (Martinić i dr. 2008, Martinić 2010, Popović 2019). Pod objektivnim opasnostima razumijevaju se vremenske prilike, odnosno neprilike bilo da se radi o kiši, grmljavinskom nevremenu, snježnoj mećavi, orkanskom vjetru ili magli. Veoma je čest uzrok tegoba Sunčevo zračenje zbog prevelike količine UV-zraka i vrućine, što može uzrokovati dehidraciju i sunčanicu. Opasnosti od divljih životinja mnogo su manje od ljudskoga straha. Ako se krećemo dovoljno "glasno«, životinje će same pobjeći, a eventualnu opasnost predstavljaju kukci, npr. krpelji. Za razliku od objektivnih opasnosti, subjektivne opasnosti nastaju zbog »ljudskoga faktora«, krivih procjena i planova, nedovoljne pripremljenosti ili neispravnosti opreme, najčešće kao posljedica nezdrava shvaćanja i precjenjivanja svojih mogućnosti. One se mogu predvidjeti i gotovo sasvim izbjeći. Drugo, razvrstavanje potencijalnih opasnosti moguće je u tri kategorije: (a) okolišne opasnosti (b) infrastrukturne opasnosti i (c) opasnosti vezane uz predispozicije i karakter posjetitelja (Landekić 2020). Navedeni obrazac, tj. razvrstavanje opasnosti ima ulogu pomoćnoga alata za ocjenitelja/auditora u postupku terenskoga uočavanja i prepoznavanja potencijalnih opasnosti.

Balansiranje između rizika i koristi vrlo je važno iz društvenoga, individualnoga i organizacijskoga aspekta. Kada govorimo o društvenom aspektu, prevelika primjena kontrolno-sigurnosnih mjera, posebno onih koje zabranjuju pristup ili ograničavaju sudjelovanje, može rezultirati: (a) gubitkom mogućnosti za rekreaciju, (b) smanjenje mogućnosti učenja i (c) ograničavanje ekonomskoga potencijala zaštićenoga područja. Na individualnoj osnovi važno je razumjeti kako posjetitelji gledaju na rizik i kako ga prihvaćaju. Na spremnost pojedinca da preuzme rizik uglavnom utječe mogući dobitak u obliku autentičnoga i jakoga doživljaja. U okviru organizacijskoga aspekta krive mjere ili neprimjena mjera za kontrolu rizika može negativno utjecati na aspekt zaštite prirode, reputaciju zaštićenoga područja, financijsku održivost zaštićenoga područja ugroženu mogućim parničnim postupcima i odštetnim zahtjevima (slika 1) itd. (VSCG 2015, Landekić 2020). 


\section{OZLJEDA POSJETITELJA (npr. lom potkoljenice) VISITOR INJURY (eg. lower leg fracture)}

(a) postojeće stanje u zaštićenim područjima

(a) current situation in protected areas

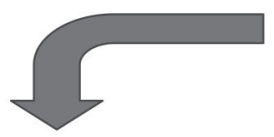

- nije implementiran sustav upravljanja rizicima

- no risk management system has been implemented

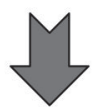

- parnični postupak (potraživanje odštetnog zahtjeva) - legal proceedings (insurance claim)

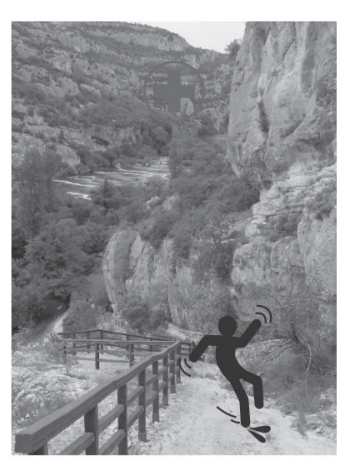

(b) stanje kojem treba težiti

(b) target conditions
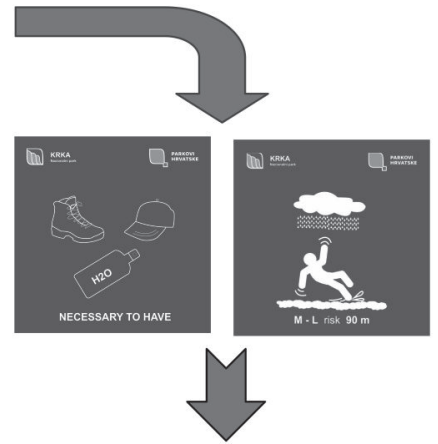

- implementiran sustav upravljanja rizicima - nema osnove za parnični postupak - implemented risk management system - no basis for legal proceedings

Slika 1. Neprihvatljiv i prihvatljiv model upravljanja rizicima pri posjećivanju zaštićenim područjima

Fig. 1 Unacceptable and acceptable model of visitor risk management in protected areas

\section{Prikaz triju elemenata upravljanja rizicima u zaštićenim područjima prirode Presentation of three elements of risk management in protected nature areas}

Osnovu sustava upravljanja rizicima pri posjećivanju zaštićenih područja čini protokol inspekcije rizika, posebno na pješačkoj infrastrukturi (slika 2). To razumijeva provođenje dokumentirane i testirane »korak po korak« procedure internoga sigurnosnoga audita ocjene rizika pomoću formalnih obrazaca u definiranim intervalima. Nadogradnju toga sustava čini shema (slika 2) »Take a Brake« (TaB) koja predstavlja programirani režim svladavanja uspona kod vrlo zahtjevnih dionica pješačke infrastrukture. Navedena shema TaB svakomu posjetitelju, na temelju dobne skupine kojoj pripada i samoocjene vlastitoga kondicijskoga potencijala, sugerira režim svladavanja staze. Daljnju nadogradnju sustava čine mrežni interaktivni modeli pješačke infrastrukture pojedinoga lokaliteta (slika 2) koji u realnom vremenu upravi zaštićenoga područja pružaju povratne informacije od posjetitelja vezano uz individualne dojmove, npr. uočena oštećenja i/ili opasnosti i dr.

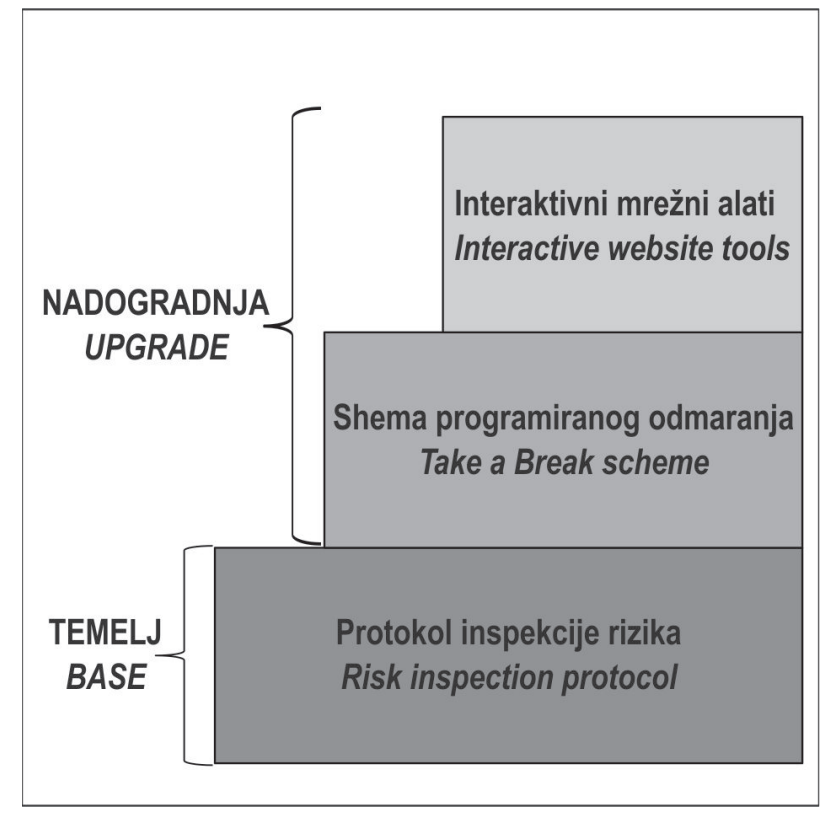

Slika 2. Elementi modela upravljanja rizicima pri posjećivanju zaštićenih područja

Fig. 2 Elements of a visitor risk management model for protected areas 


\subsection{Protokol infrastrukturne inspekcije} rizika u zaštićenim područjima - Protocol for infrastructure inspection of risks in protected areas

Infrastrukturna inspekcija i ocjena rizika za posjetitelje razumijeva proces koji treba rezultirati listom svih mogućih opasnosti i njima pripadajućih rizika, što čini osnovu sustava upravljanja rizicima pri posjećivanju zaštićenih područja. U okviru navedenoga protokola ocjena je rizika polazišna točka u određivanju vrste i sadržaja akcija koje će poduzeti uprava zaštićenoga područja. Ocjena rizika pojedine aktivnosti ili lokaliteta ne ovisi samo o razini aktivnosti već i o broju uočenih opasnosti unutar "putnoga okoliša« posjetitelja (Landekić 2020). Interni sigurnosni audit pješačke infrastrukture predstavlja strukturiranu proceduru inspekcije, pomoću formalnih obrazaca, dizajniranu specifično za (a) procjenu trenutačne zaštite i sigurnosti sustava predmetnoga zaštićenoga područja, (b) identifikaciju signifikantnih rizika za osoblje i posjetitelje (slika 3), (c) definiranje i primjenu preventivnih mjera (slika 3), te (d) za pomoć u praćenju usklađenosti sa zakonodavstvom koje je vezano uz sigurnost i zdravlje posjetitelja zaštićenoga područja (WACALM 1997a i 1997b, VSCG 2015).
Sigurnosni audit na pješačkoj infrastrukturi i/ ili rekreacijskim lokalitetima može provoditi osoblje zaštićenoga područja i/ili vanjski stručnjak (ovlašteni inženjer). Frekventni lokaliteti i pješačka infrastruktura podliježu rutinskoj inspekciji rizika, a učestalost inspekcije ovisi o razini uporabe i/ili o mogućem riziku. Definirani vremenski interval provođenja sigurnosnih audita inspekcije rizika može biti:

(a) godišnji, npr. kod opasnosti niskoga rizika koje povremeno mogu kulminirati na određenom lokalitetu, npr. povećana populacija zmija, stršljena, krpelja i sl.

(b) kvartalni, npr. kod opasnosti srednjega i visokoga rizika

(c) ad hoc, npr. po dojavi osoblja parka ili posjetitelja nakon jakih kiša, nakon jakoga vjetra i sl.

U okviru protokola sigurnosnih audita fokus se stavlja na okolišne i infrastrukturne opasnosti. Opasnosti vezane uz predispozicije i karakter posjetitelja nisu uključene u protokol sigurnosnoga audita jer njih nije moguće svrstati u vremenske okvire. Definiranje, odabir i primjena sigurnosnih mjera temelji se na listi utvrđenih opasnosti i njima pripadajućih rizika, a mogu se odnositi na:

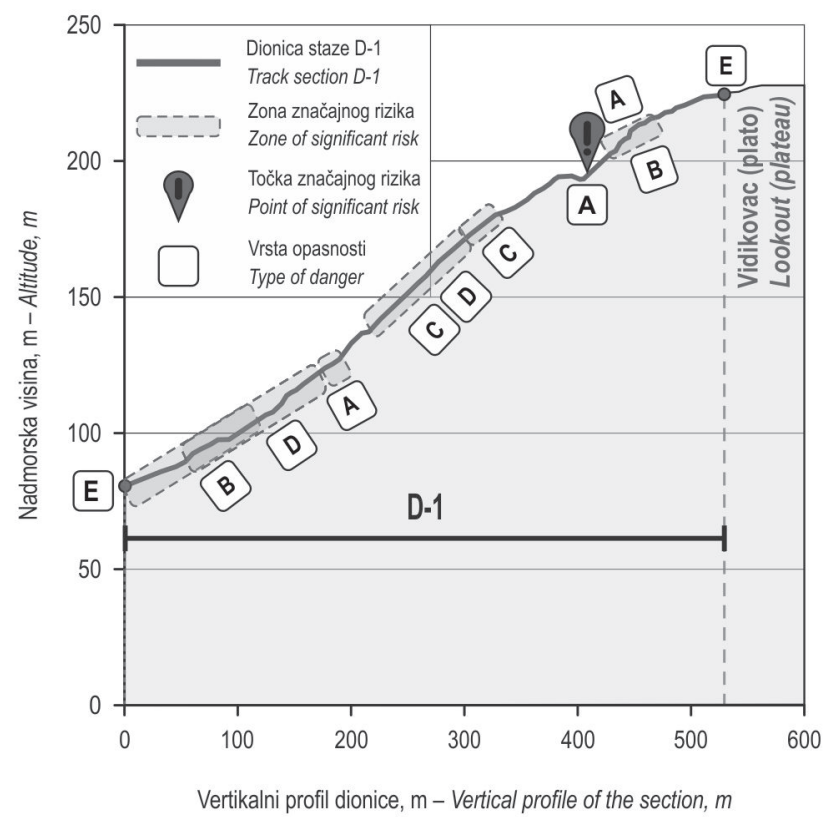

OPĆI ZNAKOVI UPOZORENJA - GENERAL WARNING SIGNS
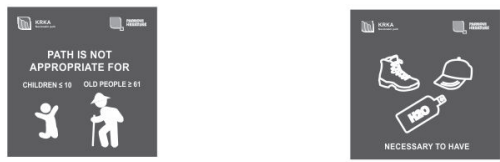

CILJANI ZNAKOVI UPOZORENJA - TARGET WARNING SIGNS

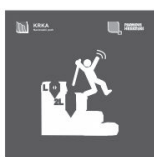

A

Opasnost od pada posjetitelja u dubinu zbog (pre)visokog gazišta kamenih stepenica Risk of visitors falling into depth due to (too) high stone stair treads
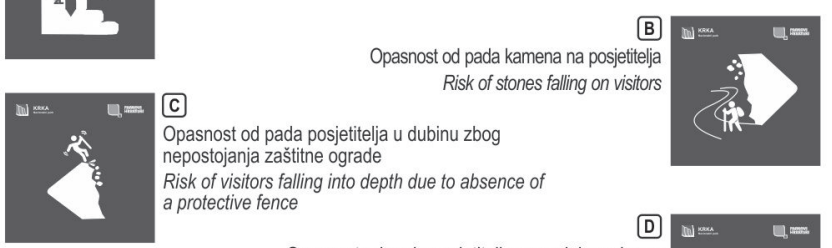

nepostojanja zaštitne ograde

Risk of visitors falling into depth due to absence of a protective fence
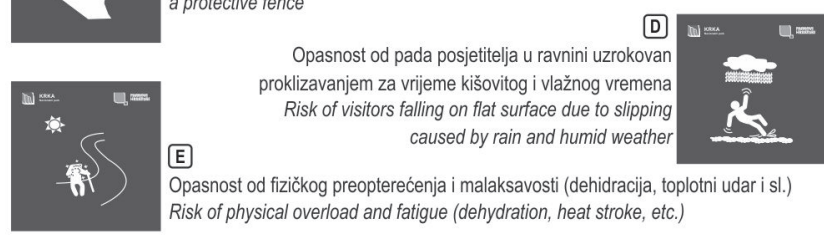

Slika 3. Detektirane opasnosti i znakovi upozorenja na dionici D-1 staze »Niz ploču« u Nacionalnom parku Krka Fig. 3 Detected hazards and warning signs on section D-1 of the trail »Niz ploču« in Krka National Park

- uklanjanje rizika kada je rizik procijenjen kao jako visok; moguća je mjera, primjerice, izostav- ljanje rekreacijske aktivnosti iz ponude na svim ili na određenim lokalitetima 
- prijenos dijela rizika radi smanjivanja odgovornosti za nesreću, npr. upozoravanjem posjetitelja čime im se osigurava da budu informirani $u$ slučaju rizika (na ulaznicama, informativnim pločama, usmeno prije početka organizirane aktivnosti i sl.)

- smanjenje mogućnosti rizika tako da se smanji vjerojatnost da se nesreća dogodi, npr. u slučaju osrednjega rizičnoga potencijala omogućavanje pristupa samo uz pratnju voditelja ili sudjelovanje uz instruktora

- smanjenje djelovanja rizika, što znači minimalizirati štete nastale od nesreće, npr. u slučaju osrednjega rizičnoga potencijala ograničavanje ili kontroliranje pristupa

- prihvaćanje rizika kada je on unutar prihvatljivih granica, nizak ili nebitan, npr. opasnost od gmazova i sl.

\subsection{Shema programiranoga odmaranja $u$ upravljanju rizicima - »Take a Brake« scheme in risk management}

Vrlo raširen oblik posjećivanja zaštićenoga područja jest pješačenje po stazama od kojih neke, cijelom trasom ili u određenom dijelu (dionici), mogu biti izrazito zahtjevne, $\mathrm{u}$ prvom redu zbog duljine i/ili svladavanja značajnih visinskih razlika, tipa materijala od kojega su izgrađene i dr. Takvi fizički napori kojima su izloženi posjetitelji zaštićenoga područja mogu imati širok spektar popratnih pojava, $u$ rasponu od onih koje uzrokuju manje nelagode do onih opasnih za život (Physical Activity and Health 1999). Stoga, kao nužna sastavnica sustava upravljanja rizicima pri posjećivanju zaštićenih područja, nameće se obveza parkovnih uprava da informiraju posjetitelje o mogućim izvanrednim fizičkim naprezanjima kojima će se izložiti, npr. pri pješačenju, planinarenju, ronjenju i dr.

Shema (slika 4) »Take a Brake«(TaB), koja predstavlja programirani režim svladavanja uspona kod vrlo zahtjevnih dionica pješačke infrastrukture, čini prvu nadogradnju sustava upravljanja rizicima pri posjećivanju zaštićenih područja. U pripremi takve sheme, za odabrane dionice staze, klasa fizičkoga opterećenja i njima pripadajuća razina opće fizičke spreme za svakoga uzorkovanoga posjetitelja određuje se prema izračunu postotnoga povećanja frekvencije srca tijekom svladavanja pješačke staze. Temeljem dobivenih rezultata, terenskim mjerenjem na samoj dionici staze, odabire se optimalna matrica za ocjenu rizika i razrađuje se shema programiranoga odmaranja (shema $\mathrm{TaB}$ ) kojom se svakomu posjetitelju na temelju dobne skupine kojoj pripada i samoocjene vlastitoga kondicijskoga potencijala sugerira režim svladavanja staze. Tako, na primjer, za posjetitelja u dobi od 50 godina i prosječne opće fizičke spreme predmetna je dionica staze srednje zahtjevna (umjereni rizik) te posjetitelju sugerira »žuti režim« svladavanja staze (slika 4). Režim uključuje vrstu, lokaciju i broj odmorišnih stajališta te minimalno vrijeme predaha/odmora na takvim stajalištima (slika 4).

\begin{tabular}{|c|c|c|c|c|c|c|}
\hline \multicolumn{7}{|c|}{$\begin{array}{l}\text { VAŠA OSOBNA PROCJENA RAZINE OPĆE FIZIČKE SPREME (npr. prosječna) } \\
\text { YOUR PERSONAL ASSESSMENT OF THE LEVEL OF GENERAL PHYSICAL FITNESS (eg. average) }\end{array}$} \\
\hline \multirow{5}{*}{ 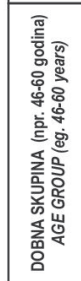 } & & $\begin{array}{l}\text { Niska } \\
\text { Low }\end{array}$ & \begin{tabular}{|c|} 
Ispod \\
prosječna \\
Under average
\end{tabular} & $\begin{array}{l}\text { Prosječna } \\
\text { Average }\end{array}$ & $\begin{array}{c}\text { Visoka } \\
\text { High }\end{array}$ & $\begin{array}{l}\text { Izrazito visoka } \\
\text { Extremely } \\
\text { high }\end{array}$ \\
\hline & $\leq 20$ & 2 & 1 & UU & 0 & 0 \\
\hline & $21-45$ & 4 & 3 & & \multirow{3}{*}{\multicolumn{2}{|c|}{$\begin{array}{l}\text { Pratite ŽUTI režim } \\
\text { savladavanja dionice! } \\
\text { Follow the YELLOW } \\
\text { mode of mastering the } \\
\text { stock! }\end{array}$}} \\
\hline & 46.60 & 17 & & 4 & & \\
\hline & $\geq 61$ & 10 & 7 & 5 & & \\
\hline \multicolumn{2}{|c|}{$\begin{array}{l}\text { Kategorija zahtjevnosti } \\
\text { Category of demands }\end{array}$} & \multicolumn{2}{|c|}{$\begin{array}{l}\text { Rizik } \\
\text { Risk }\end{array}$} & $\begin{array}{l}\text { Vrijednost } \\
\text { Value }\end{array}$ & $\begin{array}{r}\text { Sug } \\
\text { Sugge }\end{array}$ & $\begin{array}{l}\text { irani broj odmora } \\
\text { ed number of breaks }\end{array}$ \\
\hline \multicolumn{2}{|c|}{$\begin{array}{l}\text { Zelena } \\
\text { Green }\end{array}$} & \multicolumn{2}{|c|}{$\begin{array}{l}\text { Mali } \\
\text { Small }\end{array}$} & $0-1$ & & $\begin{array}{l}2 \text { odmora } \\
2 \text { breaks }\end{array}$ \\
\hline \multicolumn{2}{|c|}{$\begin{array}{l}\text { Žuta } \\
\text { Yellow }\end{array}$} & \multicolumn{2}{|c|}{$\begin{array}{l}\text { Umjereni } \\
\text { Moderate }\end{array}$} & $2-4$ & & $\begin{array}{c}3 \text { odmora } \\
3 \text { breaks }\end{array}$ \\
\hline \multicolumn{2}{|c|}{$\begin{array}{l}\text { Crvena } \\
\text { Red }\end{array}$} & \multicolumn{2}{|c|}{$\begin{array}{l}\text { Veliki } \\
\text { High }\end{array}$} & $5-10$ & & $\begin{array}{c}5 \text { odmora } \\
5 \text { breaks }\end{array}$ \\
\hline
\end{tabular}

Slika 4. Postupak odabira režima svladavanja dionice staze sa sugeriranim brojem odmora

Fig. 4 The process of selecting the mode/regime of mastering the track section with the suggested number of breaks

Praktična primjena sheme TaB sadrži: (1) obavijesnu tablu postavljenu na početku staze na osnovi koje svaki posjetitelj može odrediti osobni optimalni režim svladavanja staze kao zeleni, žuti ili crveni režim (slika 4); (2) izvedena i označena odmorišta na trasi staze, pri čemu su lokacije odmorišta određene prema zahtjevima za odmorima najrizičnijega režima (crveni) i mogućnostima izvedbe odmorišta na terenu na razini mikrolokacije; (3) obavijesnu tablu na svakom odmorištu kojom se za pojedini režim svladavanja određuje jedna od dviju aktivnosti: »prolazak bez stajanja« ili »odmor«, pritom je u slučaju obvezujućega odmora na tabli označeno i trajanje odmora u minutama (Martinić i dr. 2015, Landekić i dr. 2015, 2018).

\subsection{Uloga interaktivnih mrežnih alata u upravljanu rizicima - The role of interactive website tools in risk management}

Danas, zbog raširenosti primjene informacijskih tehnologija i mrežnih servisa, primjena interaktivnoga alata u obliku virtualnoga vertikalnoga mo- 
dela pješačke infrastrukture (slika 5) čini drugu nadogradnju sustava upravljanja rizicima pri posjećivanju zaštićenih područja. Internetski interaktivni alati/aplikacije mogu pomoći u upravljanju rizicima povezanim sa sigurnošću i zdravljem posjetitelja u zaštićenim područjima. Mrežna aplikacija u obliku virtualnoga vertikalnoga modela pješačke infrastrukture (slika 5) može imati različite funkcije u pružanju informacija posjetiteljima prije boravka u zaštićenom području (npr. kulturne vrijednosti, potencijalne opasnosti na stazi i sl.), ali i u prikupljanju povratnih informacija tijekom i/ili nakon boravka posjetitelja u zaštićenom području, npr. posjetiteljev doživljaj zaštićenoga područja na predmetnoj dionici, zadovoljstvo kretnom infrastrukturom, uočena oštećenja i/ili opasnosti na stazi, izbjegnute ozljede, zadobivene lakše ozljede, ocjena fizičke (pre)zahtjevnosti dionice staze i dr.

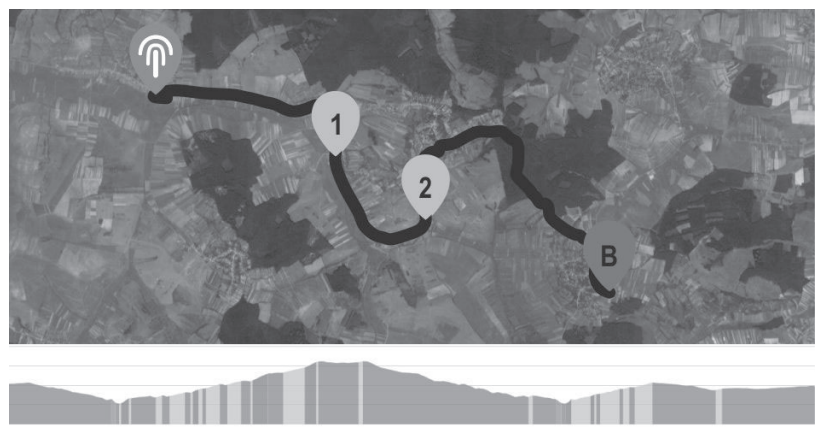

Slika 5. Primjer interaktivnoga vertikalnoga modela pješačke infrastrukture

Fig. 5 An example of an interactive vertical model of pedestrian infrastructure

\section{Diskusija i zaključci - Discussion and conclusion}

Proaktivni pristup posjećivanju prirode i rast broja posjetitelja brže od razvoja i integracije sustava upravljanja rizicima upravu i zaposlenike hrvatskoga parkovnoga sustava sve više opterećuje dodatnim obavezama, parničnim postupcima i odštetnim zahtjevima koje u slučajevima ozljeđivanja posjetitelji potražuju (Landekić 2020). Analiza zakonodavnoga okvira Republike Hrvatske rezultirala je obvezujućom odredbom Zakona o pružanju usluga u turizmu (NN 130/17) slijedom koje pravne i fizičke osobe koje pružaju turističke usluge aktivnoga i pustolovnoga turizma (npr. planinarenje, biciklizam i sl.) moraju procijeniti rizike te izraditi planove i procedure otklanjanja opasnosti, odnosno razviti i primijeniti sustav upravljanja rizicima. Odgovor uprave zaštićenoga područja na navedenu obavezu mora biti primjena adekvatnoga sustava procjene i upravljanja rizicima.

Suvremeni pristup upravljanja uočenim rizicima uključuje proaktivan pristup, gdje se rizik proučava kao prilika, a ne samo kao prijetnja te razumijeva sljedeće: (a) vrednovanje je rizika kontinuirani proces; (b) u upravljanju rizicima sudjeluju svi (stručnjaci, zaposlenici i posjetitelji); (c) uprava zaštićenoga područja preuzima odgovornost za vrednovanje i upravljanje rizicima, pri čemu definira akcijski plan upravljanja rizicima pri posjećivanju; (d) neprekidno se preventivno promatraju i vrednuju stvarni izvori rizika (Buntak i dr. 2014). Važno je naglasiti da nije uvijek moguće i nije poželjno ukloniti sve rizike. Mjere poduzete za kontrolu rizika moraju biti uravnotežene s drugim čimbenicima, kao što su očuvanje vrijednosti zaštićenoga područja i/ili sloboda posjetitelja za istraživanjem i spontanim doživljavanjem prirodnoga ambijenta. Odgovorno preuzimanje rizika trebalo bi se smatrati normalnim i nije potrebno obeshrabriti posjetitelje kako bi poduzimali određene aktivnosti isključivo na osnovi toga što postoji rizik. Upravljanje sigurnošću posjetitelja sastoji se u pružanju opće koristi društvu, lokalnoj zajednici i pojedincima uravnoteživanjem koristi s jedne strane te potencijalnih rizika s druge strane. Važno je istaknuti da se ne radi o stvaranju društvenoga okruženja potpuno bez rizika, tj. »nultoga rizika«, te zaustavljanju važnih rekreativnih i obrazovnih aktivnosti gdje se rizici razmatraju i prihvaćaju.

Temeljem svega navedenoga mogu se izvesti ovi zaključci:

- u prvom koraku uprave zaštićenih područja u hrvatskom parkovnom sustavu trebaju detektirati »nulto stanje« upravljanja rizicima pri posjećivanju njihovih zaštićenih područja

- nadležna tijela za hrvatski parkovni sustav dužna su pripremiti vodič s jedinstvenim nacionalnim protokolom i pripadajućim obrascima za provođenje internih audita ocjene rizika na pješačkoj infrastrukturi u zaštićenim područjima

- sukladno zakonodavnomu okviru, javne ustanove koje u ponudi imaju usluge aktivnoga i pustolovnoga turizma moraju procijeniti rizike te izraditi planove i procedure otklanjanja opasnosti

- parkovne uprave koje su dosad razvile pojedine elemente sustava upravljanja posjetiteljima radi unapređenja sustava trebaju provoditi edukacijske, informativne i tehničko-organizacijske mjere za smanjenje zdravstvenih rizika pri posjećivanju, vodeći se primjerima sheme »Take a Brake« (TaB) i mrežne aplikacije za davanje i prikupljanje informacija od posjetitelja. 


\section{Zahvala - Acknowledgement}

Istraživanje je provedeno $\mathrm{u}$ okviru projekta »Izrada protokola inspekcije rizika na pješačkoj infrastrukturi lokaliteta Roški slap« koji je financirala Javna ustanova »Nacionalni park Krka«.

\section{Literatura - References}

Buntak, K., I. Drožđek, M. Košćak, 2014: Metodologija implementacije upravljanja rizicima FMEA metodom. Technical journal, 8(1): 25-33.

Forrester, J. D., C. P. Holstege, 2009: Injury and illness encountered in Shenandoah National Park. Wilderness \& Environmental Medicine, 20(4): 318-326. https://doi. org/10.1580/1080-6032-020.004.0318

Landekić, M., I. Martinić, M. Bakarić, 2015: Upravljanje rizicima prilikom posjećivanja Nacionalnog parka »Krka« - ispitivanje sigurnosti pješačkih staza. Znanstveno-stručni skup Vizija i izazovi upravljanja zaštićenim područjima prirode $\mathrm{u}$ RH, Aktivna zaštita i održivo upravljanje u Nacionalnom parku »Krka«, Šibenik, 28. rujna - 3. listopada 2015. (poster)

Landekić, M., I. Martinić, F. Galić 2018: Razvoj sheme programiranoga odmaranja na pješačkoj stazi »Podgarić Garić grad« u regionalnom parku Moslavačka gora. Nova mehanizacija šumarstva, 39(1): 67-82.

Landekić, M., 2020: Izrada protokola inspekcije rizika na pješačkoj infrastrukturi lokaliteta Roški slap. Šumarski fakultet Sveučilišta u Zagrebu, projektno izvješće, 1-46.

Martinić, I., M. Kosović, I. Grginčić, 2008: Upravljanje rizicima pri posjećivanju i rekreacijskim aktivnostima u zaštićenim područjima prirode. Šumarski list, 132(1-2): 33-42.

Martinić, I., 2010: Upravljanje zaštićenim područjima prirode - planiranje, razvoj i održivost. Sveučilište u Zagrebu, Šumarski fakultet, 1-367.

Martinić, I., M. Landekić, M. Bakarić, D. Marguš, A. Jurković, 2015: Smanjenje opterećenja posjetitelja na pješačkim stazama u zaštićenim područjima primjenom sheme programiranog odmaranja. Šumarski list, 139(5-6): 233-244.

Newman, S. B., 2007: Visitor injury in National Parks: The magnitude of the problem and how it is being addressed. PHA Scientific Session and Event Listing, November 07, 2007. Available at: https://apha.confex. com/apha/135am/techprogram/paper_166296.htm (Pristupljeno 1. 6. 2020.)

Physical Activity and Health, 1999: Chapter 4 - The Effects of Physical Activity on Health and Disease. A report of the surgeon general. National Center for Chronic Disease Prevention and Health Promotion, Division of Nutrition and Physical Activity.

Popović, K., 2019: Razvoj projekta za upravljanje rizicima pri posjećivanju zaštićenih područja. Diplomski rad, Šumarski fakultet Sveučilišta u Zagrebu, 1-35.

Stephens, B. D., D. S. Diekema, E. J. Klein, 2005: Recreational injuries in Washington state national parks. Wilderness \& Environmental Medicine, 16(4): 192-197. https:// doi.org/10.1580/1080-6032(2005)16[192:RIIWSN]2.0.CO;2

Stock, G. M., B. D. Collins, D. J. Santaniello, V. L. Zimmer, G. F. Wieczorek, J. B. Snyder, 2012: Historical rock falls in Yosemite National Park (1857-2011). U.S. Geological Survey Data Series, 746, 17 p.

VSCG (The Visitor Safety in the Countryside Group), 2015: Managing visitor safety in the historic built environment: principles \& practice. The Visitor Safety in the Countryside Group, 49 p.

WACALM, 1997a: Visitor Risk Management, Policy Statement No.53. Department of Conservation \& Land Management, Western Australia, 4 p.

WACALM, 1997b: Visitor Risk Management - Operational Guidelines. Department of Conservation \& Land Management, Western Australia.

Zakon o pružanju usluga u turizmu (NN 130/17). https:// www.zakon.hr/z/343/Zakon-o-pru\%C5\%BEanju-usluga-u-turizmu (Pristupljeno 20. 11. 2019.) 


\section{Abstract}

\section{Visitor Safety and Risk Management in Forest Districts of Protected Nature Areas}

The last two decades have been marked, especially in developed countries of Western Europe and the world, by significant changes in the management of health and safety of visitors to forest ecosystems in protected nature areas. Protected area administrations are increasingly developing different models and implementing many elements of the visitor risk management system. Such systems include concepts oriented to risk management in order to increase the safety of visitors, especially when their physical engagement is required. Accordingly, the introductory part of the paper outlines the role, purpose and objective of the risk management system when visiting protected areas. The central part of the paper, on the example of pedestrian infrastructure in the protected area, outlines the negative aspects of the current situation, the consequences of inadequate risk control and the categorization of potential hazards. The results of the work, through specific examples, clarify three key segments of the risk management system: (a) the risk inspection protocol; $(b) » T a k e$ a Break " scheme and (c) the role of interactive website tools. The final part of the paper presents the operationalization and implementation of a visitor risk management system for a protected area using the example of a 'pedestrian' park infrastructure.

Keywords: forestry, protected area, visitor safety, risk management

Primljeno (Received): 8. 6. 2020.

Prihvaćeno (Accepted): 13. 7. 2020.
Adresa autorâ - Authors' address:

Doc. dr. sc. Matija Landekić* e-pošta: mlandekic@sumfak.unizg.hr Prof. dr. sc. Ivan Martinić e-pošta: imartinic@sumfak.unizg.hr Dr. sc. Matija Bakarić e-pošta:mbakaric@sumfak.unizg.hr Prof. dr. sc. Mario Šporčić e-pošta: sporcic@sumfak.unizg.hr Šumarski fakultet Sveučilišta u Zagrebu Zavod za šumarske tehnike i tehnologije Svetošimunska 25 HR - 10000 Zagreb HRVATSKA

* Glavni autor - Corresponding author 